\title{
Detection of a new summit crater on Bezymianny Volcano lava dome: satellite and field-based thermal data
}

\author{
Adam J. Carter • Michael S. Ramsey • \\ Alexander B. Belousov
}

Received: 24 July 2006 / Accepted: 22 November 2006

(C) Springer-Verlag 2007

\begin{abstract}
An explosive eruption occurred at the summit of Bezymianny volcano (Kamchatka Peninsula, Russia) on 11 January 2005 which was initially detected from seismic observations by the Kamchatka Volcanic Eruption Response Team (KVERT). This prompted the acquisition of 17 Advanced Spaceborne Thermal Emission and Reflection Radiometer (ASTER) satellite images of the volcano over the following 10 months. Visible and infrared data from ASTER revealed significant changes to the morphology of the summit lava dome, later seen with field based thermal infrared (TIR) camera surveys in August 2005. The morphology of the summit lava dome was observed to have changed from previous year's observations and historical accounts. In August 2005 the dome contained a new crater and two small lava lobes. Stepped scarps within the new summit crater suggest a partial collapse mechanism of formation, rather than a purely explosive origin. Hot pyroclastic deposits were also observed to have pooled in the moat between the current lava dome and the 1956 crater wall. The visual and thermal data revealed a complex eruption sequence of explosion(s), viscous lava extrusion, and finally the formation of the collapse crater. Based on this sequence, the conduit could have become blocked/ pressurized, which could signify the start of a new behav-
\end{abstract}

Editorial responsibility A. Harris

A. J. Carter $(\bowtie) \cdot$ M. S. Ramsey

Department of Geology and Planetary Science,

University of Pittsburgh,

200 SRCC Building,

Pittsburgh, PA 15260-3332, USA

e-mail: ajc44@pitt.edu

\section{A. B. Belousov}

Institute of Marine Geology and Geophysics,

Nauki str, 1,

Yuzhno-Sakhalinsk, Russia ioural phase for the volcano and lead to the potential of larger eruptions in the future.

Keywords Bezymianny Kamchatka $\cdot$ Remote sensing · ASTER · FLIR

\section{Introduction}

Bezymianny $\left(55.98^{\circ} \mathrm{N}, 160.59^{\circ} \mathrm{E}\right)$ is a Holocene andesitic composite volcano (Fig. 1a) with a summit elevation of approximately $2,900 \mathrm{~m}$ and is located $350 \mathrm{~km}$ north of Petropavlovsk-Kamchatsky (Bogoyavlenskaya et al. 1991). It forms part of the Klyuchevskaya group within the central Kamchatka depression. Previously inactive for about 1,000 years, Bezymianny reactivated in 1955 , culminating in a cataclysmic eruption on 30 March 1956 (Gorshkov 1959; Belousov 1996). This directed blast generated a $1.3 \mathrm{~km}$ (north-south) by $2.8 \mathrm{~km}$ (east-west) horseshoeshaped crater opening to the east. Following this, a longterm phase of lava dome growth began in the crater, which was mostly endogenous prior to 1969 (Bogoyavlenskaya and Kirsanov 1981). Similar to activity at Mt. St. Helens (Swanson et al. 1987), lava at Bezymianny was commonly extruded in a near-solidified state as rigid spines in different locations within the crater (Bogoyavlenskaya and Kirsanov 1981). After 1977, exogenous activity became more common, with lava lobes being emplaced periodically from a single location on the upper part of the dome, adding to its volume (Alidibirov et al. 1990; Bogoyavlenskaya and Kirsanov 1981). During the last 30 years Bezymianny has been regularly active, erupting one to two times per year on average (Belousov et al. 2002; Ramsey and Dehn 2004). However, this activity has been punctuated by much larger eruptions such as the sub-plinian events of 1985 and 1997 


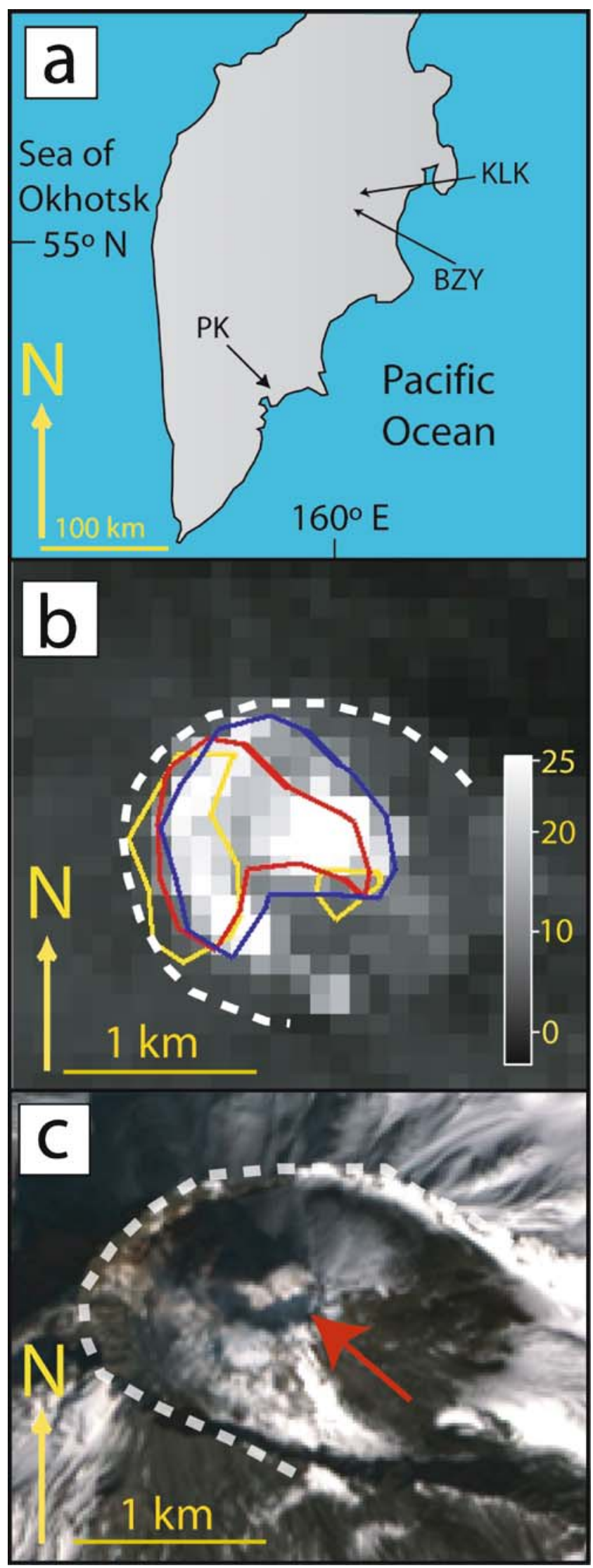

Fig. 1 Location and satellite-based observations of Bezymianny Volcano. a Map of the Kamchatka Peninsula centred on $55^{\circ} \mathrm{N}, 160^{\circ} \mathrm{E}$, with Bezymianny (BZY) and Klyuchevskoy (KLK) volcanoes located to the north of the city of Petropavlovsk-Kamchatsky (PK). b Nighttime TIR ASTER temperature image in Celsius from 15 January 2005 showing a thermal anomaly around the summit. Overlain: temporal composite overlay of the $10^{\circ} \mathrm{C}$ contour above background temperature for the 15 January (blue), 16 February (red), 4 March (yellow) images. The cooling trend with time over the dome and a sustained anomaly over the deposit within the 1956 crater is evident. c Daytime ASTER VNIR image from 12 March 2005 showing the new collapse crater evident on the dome (indicated by a red arrow)

(Alidibirov et al. 1990; Belousov et al. 2002) and the recent 9 May 2006 eruption (Kamchatka Volcanic Eruption Response Team (KVERT) Report 2006).

The remote location combined with common cloud cover make satellite and field observations of the volcano difficult. However, it remains a critical volcano to monitor due to the chance of much larger eruptions that can form ash-rich plumes which traverse into north Pacific air traffic routes (Miller and Casadevall 2000). Similar surveys have also been completed elsewhere at remote or inaccessible volcanoes such as Láscar, Chile (Oppenheimer et al. 1993 and references therein) and Mount Belinda on Montagu Island (Patrick et al. 2005) and required similar verification of results by direct field surveys.

\section{Satellite observations}

The primary satellite instrument used for higher resolution data was ASTER, which acquires reflected solar and thermally-emitted electromagnetic radiation within three spectral regions and at three spatial resolutions (Yamaguchi et al. 1998). However, initial detection of an eruption was made on 11 January by KVERT, which issued a report stating an eruption had occurred at 08:02 A.M. (UTC) and produced an 8-10 km ASL ash column (Kamchatka Volcanic Eruption Response Team (KVERT) Report 2005). The eruption was also detected by the Alaska Volcano Observatory (AVO) Advanced Very High Resolution Radiometer (AVHRR) thermal anomaly detection system (Dehn et al. 2000), which then triggered an ASTER rapid response imaging sequence that involved targeted and regular data collection (Ramsey et al. 2004). This resulted in six daytime and eleven nighttime images from January to October 2005.

The first ASTER acquisition on 15 January 2005 (described in Carter et al. 2005) revealed nighttime thermal anomalies around the summit crater as well as up to $3 \mathrm{~km}$ away (Fig. 1b). The dome region had a maximum TIRderived temperature of $26^{\circ} \mathrm{C}$ above the average background temperature $\left(-24^{\circ} \mathrm{C}\right)$, which was derived from a $20 \mathrm{~km}^{2}$ non-volcanic area to remove seasonal effects. Three 
nighttime scenes (15 January, 16 February, and 4 March 2005) show a cooling trend on the eastern portion of the dome (Fig. 1b). However, pyroclastic density current (PDC) deposits ponded between the 1956 crater wall and dome retained their heat much longer, and continued to show temperatures elevated above background during the field surveys in August 2005. On 12 March 2005, reduced shadowing in the crater and less snow cover allowed for improved viewing conditions of the dome and revealed a distinct circular crater structure at the summit (Fig. 1c). This was the first indication of a new summit pit structure on Bezymianny's dome. An ASTER-derived Digital Elevation Model (DEM) created from the 12 March images revealed a crater depth of $\sim 50 \mathrm{~m}$ and a diameter of $310 \mathrm{~m}$ north-south and $385 \mathrm{~m}$ east-west. However, the first aerial observations in July 2005 suggested the crater could be up to $200 \mathrm{~m}$ deep (O Girina, pers. Comm. 2005). The DEMderived depth was probably an underestimation due to the spatial averaging that occurs at the $30 \mathrm{~m}$ resolution of ASTER. Using an inverted, truncated cone as a simplified geometric model, with a large radius of $173.75 \mathrm{~m}$ (crater edge) and short radius of $82 \mathrm{~m}$ (inner crater base), the volumes calculated for depths of $50 \mathrm{~m}$ and $200 \mathrm{~m}$ were $2.6 \times 10^{6} \mathrm{~m}^{3}$ and $10.7 \times 10^{6} \mathrm{~m}^{3}$, respectively.

\section{Aerial and ground-based observations}

Field campaigns in August 2004 and 2005 were performed to verify the recent ASTER observations. During these, aerial high resolution TIR and visible photographic surveys of the dome and pyroclastic deposits were made from a helicopter. In August 2004 no summit crater was present; however, one year later the new summit crater and hot, ponded deposits originally detected with ASTER were verified (Fig. 2a). Thermal surveys were conducted using a Forward-Looking Infrared Radiometer (FLIR) camera. Similar surveys of volcanoes have become a useful monitoring tool in locations such as Stromboli, Italy (Harris et al. 2005) and Mount Saint Helens, USA (Vaughan et al. 2005) for example. The FLIR contains an uncooled microbolometer detector array that captures radiation from the $7.5-13 \mu \mathrm{m}$ wavelength region. Still images were extracted from video data files taken between 19 and 25 August 2005 , which were collected at a minimum of one image per second. A $24^{\circ}$ FLIR lens was used, with an instantaneous field of view (IFOV) of $1.3 \mathrm{mrad}$. Helicopter altitude was around $3500 \mathrm{~m}$ and the distance to the upper dome region varied from $600 \mathrm{~m}$ to $850 \mathrm{~m}$. Thus, the range of spatial resolutions was 0.78 to $1.11 \mathrm{~m}$. The maximum derived pixel-integrated temperature was $163^{\circ} \mathrm{C}$, with an average temperature of $10^{\circ} \mathrm{C}$ over the dome area $\left(1.27 \mathrm{~km}^{2}\right)$. Digital photograph and thermal (FLIR) image mosaics were created and four regions of interests were identified (Fig. $2 \mathrm{~b}$ and c): (1) a short ( $60 \mathrm{~m}$ long $\times 150 \mathrm{~m}$ wide) lava lobe (Lobe A); (2) a $150 \mathrm{~m}$ long lava lobe (Lobe B); (3) the new central summit crater; and (4) two flat-bottomed oval collapse pits $20 \times 30 \mathrm{~m}$ in diameter in the ponded pyroclastic deposits.

Lobe A flowed to the west and video footage showed that it exhibited partial ductile deformation, sagging back into the crater. Thus, we interpret that Lobe A had not completely solidified prior to crater formation. The flow surface of Lobe A contained deep ridges perpendicular to flow direction and the FLIR-derived temperature over its area was $10^{\circ} \mathrm{C}$, with a maximum temperature of $77^{\circ} \mathrm{C}$. Lobe B was located south of Lobe A, with no apparent crosscutting relationship to it. The flow surface was visibly smoother and lighter in colour than Lobe A and it had an average temperature of $12^{\circ} \mathrm{C}$, with a maximum of $56^{\circ} \mathrm{C}$.

The formation of a central summit crater was the most dramatic change observed at Bezymianny in recent observations. It contained concentric stepped ledges and fractures that surrounded the rim. The crater cut older lava lobes and pyroclastic material as seen in its walls. The warmest areas corresponded to more competent rock layers and hot cracks that bounded the concentric ledges. Surrounding the dome and within the main summit crater of the volcano, the moat was filled with newly-emplaced PDC deposits that contained several collapse pits. The areas within the pits had an average temperature of $33^{\circ} \mathrm{C}$, with the hottest surfaces at $124^{\circ} \mathrm{C}$. These collapse structures may be caused by PDC deposition onto (or the entrainment of) ice/snow, which was observed in ice-rich lahars by Branney and Gilbert (1995). At Bezymianny, the thickest part of this new deposit, located west of the dome summit inside the 1956 crater rim, was also the location of the small pits. It is most likely that the PDC deposit was emplaced onto the snow and ice present in this shadowed part of the crater during the January eruption. It cooled slowly over several months while differential melting occurred beneath the deposit, producing the pits (lower Fig. 2b-delimited by a black rectangle) and the thermal TIR anomaly (Fig. 1b).

\section{Discussion and conclusions}

An explosive eruption occurred at Bezymianny on 11 January 2005 and deposited juvenile and older dome material within the 1956 crater. The eruption also generated one or more PDC deposits, which, based on later field sampling, primarily contained fresh vesicular blocks and ash with smaller quantities of older, hydrothermally altered dome material. Based on the radial deposition observed, the presence of ash on the slopes outside of the 1956 crater, and the column height $(8-10 \mathrm{~km})$, we interpret that column 
Fig. 2 a Aerial, digital photograph from 19 August 2005 showing the new summit crater on the lava dome. The 1956 crater (1.3 km north-south) opening to the east is denoted by the white dashed line. b Part of the 19 August 2005 digital photograph composite taken simultaneously with FLIR observations. Lobes $\mathrm{A} / \mathrm{B}$ and the collapse crater are marked with arrows and dashed lines, with sagging back into the crater marked with arrows. In the lower right (delimited by a black rectangle) one of the oval pits observed within the ponded PDC deposits is shown. c FLIR colour composite image with a temperature range from $0^{\circ} \mathrm{C}$ to $120^{\circ} \mathrm{C}$. The temperatures were derived using an average distance to the dome of $725 \mathrm{~m}$, an assumed emissivity of 0.97 for the surface, a humidity of $30 \%$, and an atmospheric temperature of $5^{\circ} \mathrm{C}$. The stepped ledges within the crater can be seen, with both Lobes A and B partially draped into the crater
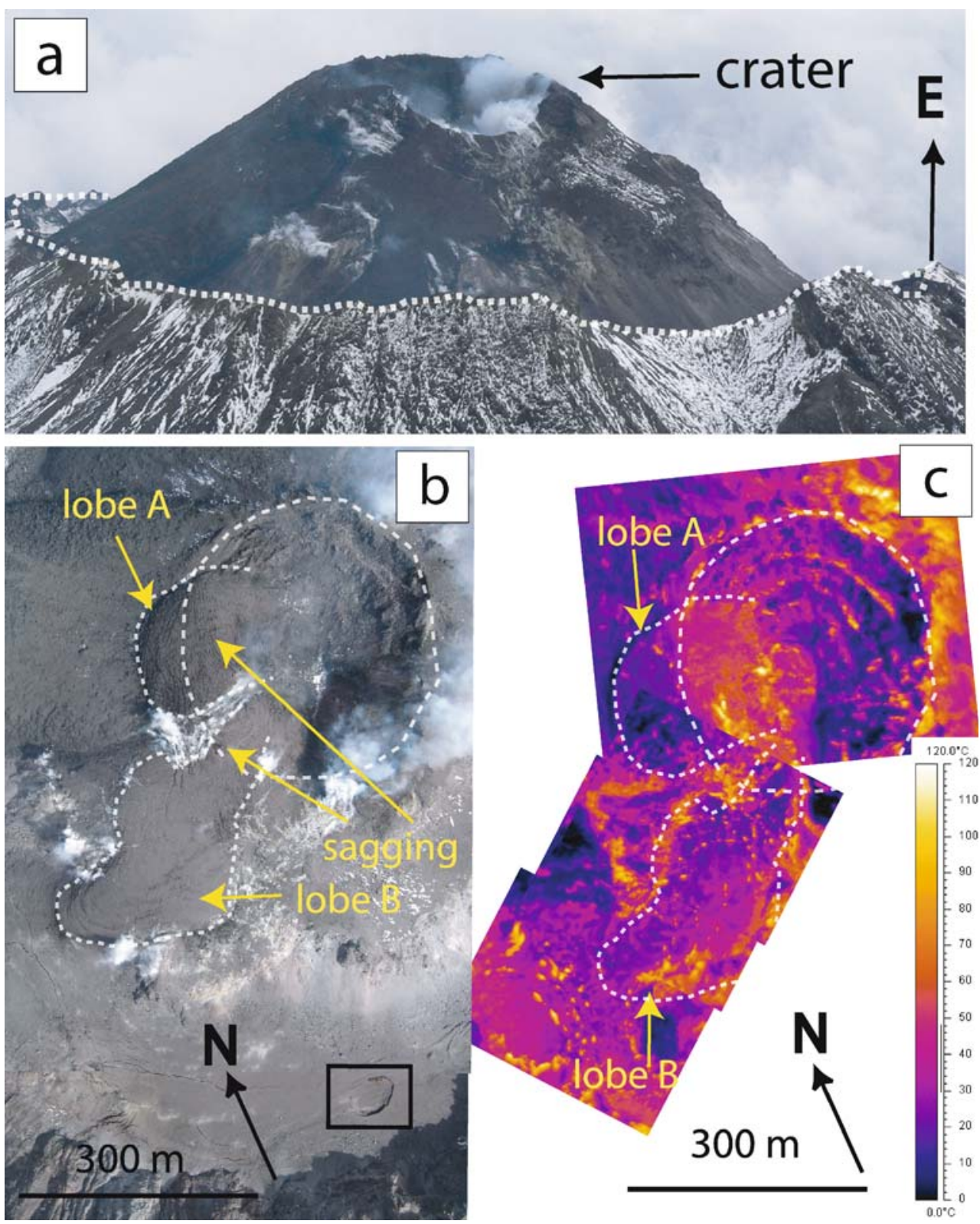

collapse most likely formed these deposits. A large fraction of the material pooled between the 1956 crater rim and the dome, with the remainder of this flow continuing down slope to the southeast, carrying hot ash and blocks with unweathered vesicular centres as far as $3 \mathrm{~km}$ from the vent.

We infer that the eruption sequence progressed from explosive to extrusive with the emplacement of two short viscous lava lobes (Lobe A and Lobe B) that appear to have erupted from near or at the summit of the existing dome, similar to the previous exogenous dome growth at Bezymianny. Following the flow emplacement, a crater with a volume estimated to be between $2.6 \times 10^{6} \mathrm{~m}^{3}$ and $10.7 \times 10^{6} \mathrm{~m}^{3}$ formed within the older lava dome. We cannot infer the exact timing of the crater formation; however, field observations confirmed the lack of a crater in August 2004 and no unusual activity was observed over August-December 2004. Based on field observations and superposition relationships we infer that a collapse at the dome summit occurred following emplacement of these lava flows to form the crater. We propose that the crater is of at least partial collapse origin, based on aerial views of Lobe A that showed a steep cliff on the western rim. In addition, some ductile deformation occurred on the flows as both lobes sagged back into the newly formed crater. This style of deformation further suggests a relatively slow, lowenergy collapse process. In addition, the collapse-origin model is supported by concentric fractures seen in proximity to the crater rim as well as stepped terraces within the crater, which could represent inward-dipping blocks. This crater-forming event was a deviation from 
recent eruptive behaviour and indicates that the sub-surface conduit structure may have been modified or partially blocked within the lava dome. We hypothesize that if this was the case, it could promote a build-up of pressure, leading to a larger eruption in the future. This was potentially validated by a larger than average eruption on 9 May 2006 that produced a $15 \mathrm{~km}$ ASL ash column, which was $5 \mathrm{~km}$ higher than most eruptions during the past five years (KVERT 2006). This new phase of activity of Bezymianny may be part of a larger cycle of explosions, dome effusion, and subsidence, as observed at Láscar volcano, Chile (Matthews et al. 1997). This work highlights a possible change in the eruptive behaviour of Bezymianny volcano, which was successfully observed first using the high resolution data from ASTER and later confirmed with detailed ground and airborne observations.

Acknowledgements This work was funded by NASA grant NNG04GO69G, as well a University of Pittsburgh International Studies Fund (ISF) grant (Ramsey and Carter 2004), and a Geological Society of America (GSA) grant (Carter 2004). Logistical and field assistance was kindly provided by E. Gordeev, O. Girina, and O. Evdokimova at the Institute of Petropavlovsk-Kamchatsky, Russia. The authors would especially like to thank R. Wessels, J. Dehn, M. Belousova, J. Eichelberger, P. Izbekov, M. West, A. Auer, and S. Wacaster for field assistance and logistics. This manuscript was greatly improved by the thorough reviews of J. Dehn and M. James. AJC would personally like to thank N. and L. Lindenfelser for edits and advice.

\section{References}

Alidibirov MA, Bogoyavlenskaya GE, Kirsanov IT, Firstov PP, Girina OA, Belousov AB, Zhdanova EYu, Malyshev AI (1990) The 1985 eruption of Bezymiannyi. Volcanol Seismol 10:839-863

Belousov AB (1996) Deposits of the 30 March 1956 directed blast at Bezymianny volcano, Kamchatka, Russia. Bull Volcanol 57:649662

Belousov A, Voight B, Belousova M, Petukhin A (2002) Pyroclastic surges and flows from the 8-10 May 1997 explosive eruption of Bezymianny volcano, Kamchatka, Russia. Bull Volcanol 64:455-471

Bogoyavlenskaya GE, Kirsanov IT (1981) Twenty five years of volcanic activity of Bezymianny. Volcanol Seismol 2:3-13 (in Russian)

Bogoyavlenskaya GY, Braitseva OA, Melekestev IV, Maksimov AP, Ivanov BV (1991) Bezymianny Volcano. In: Fedotov SA and Masurenkov YuP (eds) Active Volcanoes of Kamchatka. Nauka, Moscow 1:168-197

Branney MJ, Gilbert JS (1995) Ice-melt collapse pits and associated features in the 1991 lahar deposits of Volcán Hudson, Chile: criteria to distinguish eruption-induced glacier melt. Bull Volcanol 57:293-302
Carter AJ, Ramsey MS, Belousov A, Wessels RL, Dehn J (2005) The January 2005 eruption of Bezymianny Volcano, Russia: Comparing ground and airborne thermal camera images to rapid-response ASTER satellite data. Eos Trans AGU 86(52):V31A-V0604, Fall Meet Suppl

Dehn J, Dean KG, Engle K (2000) Thermal monitoring of North Pacific volcanoes from Space. Geology 28:755-758

Gorshkov GS (1959) Gigantic eruption of the Bezymianny volcano. Bull Volcanol 20:77-109

Harris AJH, Dehn J, Patrick M, Calvari S, Ripepe M, Lodato L (2005) Lava effusion rates from hand-held thermal infrared imagery: An example from the June 2003 effusive activity at Stromboli. Bull Volcanol 68:107-117

Kamchatka Volcanic Eruption Response Team (KVERT) Report (2005) Bezymianny Volcano, 11 January 2005. http://www.avo. alaska.edu/activity/avoreport.php?view $=$ kaminfo\&id=47\&type $=$ kaminfo\&month $=$ January\&year $=2005$. Cited January 2005

Kamchatka Volcanic Eruption Response Team (KVERT) Report (2006) Bezymianny Volcano, 9 May 2006. http://www.avo. alaska.edu/activity/avoreport.php?view $=$ kaminfo $\&$ id $=172 \&$ type $=$ kaminfo\&month $=$ May\&year $=2006$. Cited May 2006

Matthews SJ, Gardeweg MC, Sparks RSJ (1997) The 1984 to 1996 cyclic activity of Láscar Volcano, northern Chile: cycles of dome growth, dome subsidence, degassing and explosive eruptions. Bull Volcanol 59:72-82

Miller TP, Casadevall TJ (2000) Volcanic ash hazards to aviation. In: Sigurdsson H, Houghton BF, McNutt S, Rymer H, Stix J (eds) Encyclopaedia of volcanoes. Academic, San Diego, pp 915-930

Oppenheimer C, Francis PW, Rothery DA, Carlton RWT, Glaze LS (1993) Infrared image analysis of volcanic thermal features: Láscar Volcano, Chile, 1984-1992. J Geophys Res 98:4269-4286

Patrick MR, Smellie JL, Harris AJL, Wright R, Dean K, Izbekov P, Garbeil H, Pilger E (2005) First recorded eruption of Mount Belinda volcano (Montagu Island), South Sandwich Islands. Bull Volcanol 67:415-422

Ramsey MS, Dehn J (2004) Spaceborne observations of the 2000 Bezymianny, Kamchatka eruption: the integration of highresolution ASTER data into near real-time monitoring using AVHRR. J Volcanol Geotherm Res 135:127-146

Ramsey MS, Dehn J, Wessels R, Byrnes J, Duda K, Maldonado L, Dwyer J (2004) The ASTER emergency scheduling system: a new project linking near-real-time satellite monitoring of disasters to the acquisition of high-resolution remote sensing data. Eos Trans AGU 85(47), Fall Meet Suppl, SF23A-0026

Swanson DA, Dzurisin D, Holocomb RT, Iwatsubo EY, Chadwick WW Jr, Casadevall TJ, Ewert JW, Heliker CC (1987) Growth of the lava dome at Mount Saint Helens, Washington (USA), 19811983. In Fink JH (ed) The emplacement of silicic lava domes and lava flows. Geol Soc Am Spec Pap 212:1-16

Vaughan RG, Hook SJ, Ramsey MS, Realmuto VJ, Schneider DJ (2005) Monitoring eruptive activity at Mount Saint Helens with TIR image data. Geophys Res Lett 32:L19305. DOI 10.1029/ 2005GL024112

Yamaguchi Y, Kahle AB, Pniel M, Tsu H, Kawakami T (1998) Overview of Advanced Spaceborne Thermal Emission and Reflection Radiometer (ASTER). IEEE Trans on Geosci Remote Sens 36:1062-1071 